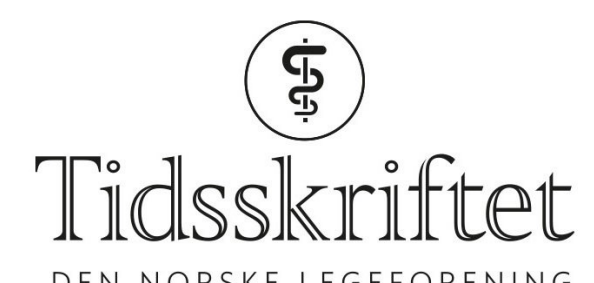

\title{
En mann i 50-årene med varierende kraftsvikt og gangvansker
}

NOE Å LAERE AV

\section{ANETTE HUUSE FARMEN}

E-post: anette.farmen@gmail.com

Nevrologisk avdeling

Oslo universitetssykehus, Rikshospitalet

og

Nevrologisk avdeling

Sykehuset Innlandet Lillehammer

Anette Huuse Farmen er spesialist i nevrologi og seksjonsoverlege.

Forfatteren har fylt ut ICMJE-skjemaet og oppgir ingen interessekonflikter.

\section{PÅL BACHE MARTHINSEN}

Radiologisk avdeling

Oslo universitetssykehus, Rikshospitalet

Pål Bache Marthinsen er spesialist i radiologi og overlege.

Forfatteren har fylt ut ICMJE-skjemaet og oppgir ingen interessekonflikter.

\section{JARLE SUNDSETH}

Nevrokirurgisk avdeling

Oslo universitetssykehus, Rikshospitalet

Jarle Sundseth er spesialist i nevrokirurgi og overlege.

Forfatteren har fylt ut ICMJE-skjemaet og oppgir følgende interessekonflikter: Han har mottatt foredragshonorar fra Bayer Pharmaceuticals.

\section{FRODE KOLSTAD}

Nevrokirurgisk avdeling

Oslo universitetssykehus, Rikshospitalet

Frode Kolstad er spesialist i nevrokirurgi og overlege.

Forfatteren har fylt ut ICMJE-skjemaet og oppgir ingen interessekonflikter.

\section{EMILIA KERTY}

Nevrologisk avdeling

Oslo universitetssykehus, Rikshospitalet

Emilia Kerty er spesialist i øyesykdommer og i nevrologi, overlege og professor emerita.

Forfatteren har fylt ut ICMJE-skjemaet og oppgir ingen interessekonflikter

\section{AHMED ELSAIS}

Nevrologisk avdeling

Oslo universitetssykehus, Rikshospitalet

Ahmed Elsais er spesialist i nevrologi og overlege.

Forfatteren har fylt ut ICMJE-skjemaet og oppgir ingen interessekonflikter 
En mann i 50-årene fikk problemer med å gå vante distanser og opplevde at kraften i bena varierte dag for dag. Trass i aggressiv behandling mot antatt årsak, ble han avhengig av rullestol.

En mann i 5o-årene med en fysisk krevende jobb og aktiv fritid fikk påvist atrieflimmer og utført ablasjon. En uke etterpå var han på fjelltur, der han kjente svakhet i bena og måtte ta pauser. Påfølgende dager hadde han vansker med å gå uten støtte, men opplevde gradvis bedring. Etter en lengre motorsykkeltur ble han symptomfri, deretter oppsto vansker med å bøye seg fremover og å gå. Tilstanden varierte fra dag til dag.

Ved undersøkelse hos nevrolog tre måneder etter symptomdebut ble det notert et fluktuerende forløp. Pasienten beskrev redusert følelse i tær og fotsåler. Vannlatningen var tidvis treg, tidvis normal. Undersøkelse av hjernenerver og overekstremiteter var upåfallende. Det var økt tonus i høyre underekstremitet. Sensibiliteten var flekkvis redusert distalt for Th11-Th12. Det var parese grad 4 - for fleksjon i venstre hofte og $3^{+}$for hamstrings bilateralt, men kraften over anklene var god. Gangen var spastisk og høyre patellarrefleks forøket. Akillesrefleksene var normale, og man fant mulige dorsale napp på plantarrefleks. Supplerende utredning viste spinalvæske med økt protein på o,9o g/l $(0,15-0,55)$, normalt celletall $3 \cdot 10^{6} / \mathrm{l}$ celler $(<5)$, normal cytologi negativ for borreliaantistoffer. Isoelektrisk fokusering viste ett bånd.

Forhøyet proteinnivå er en sensitiv, men uspesifikk indikator på patologi i sentralnervesystemet. Forhøyet proteinnivå finnes ved infeksjoner, intrakranial blødning, multippel sklerose (MS) og andre inflammatoriske, demyeliniserende tilstander som neuromyelitis optica og akutt disseminert encefalomyelitt, malignitet, høy alder og enkelte endokrine forstyrrelser $(1,2)$. Ett bånd ved isoelektrisk fokusering regnes ikke som patologisk.

Nevrografi viste manglende F-respons. Elektromyografi viste denervasjonsaktivitet og fascikulasjoner som ved affeksjon av nedre motornevron.

F-responsen er et indirekte mål på funksjon proksimalt i motornevronene. Denne kan mangle ved tidlig polyradikulitt og myelitt. Elektromyografi skiller myopatiske og nevrogene forandringer i nedre motornevroner.

MR caput viste spredte uspesifikke høysignalforandringer periventrikulært, der demyeliniserende forandringer eller kronisk iskemi ikke kunne utelukkes. MR totalcolumna viste uttalt ødem og diffus kontrastoppladning fra nivå TH4/5 og t.o.m. konus, mulig forenlig med demyeliniserende forandringer.

Uspesifikke hvitsubstansforandringer i hjernen er relativt vanlig og kan indikere småkarsykdom. Pasienter med slike tegn på MR bør ifølge norske anbefalinger kartlegges med tanke på risikofaktorer for arteriosklerose og anamnestisk for arvelige tilstander (3).

Man mistenkte inflammatorisk myelitt og startet behandling med intravenøs metylprednisolon, 1 ooo $\mathrm{mg} \times 1 \mathrm{i}$ tre dager på lokalsykehus. Etter første kur utviklet pasienten tilnærmet paralyse i underekstremitetene. Tre dager etter avsluttet behandling ble kraften bedre igjen. Pasienten ble overflyttet til et universitetssykehus, der man fant sentrale pareser i underekstremitetene, svekket sensibilitet for stikk og berøring distalt med gradvis normalisering ved Th1o, dorsale napp ved plantarrefleks og tidvis behov for urinkateterisering.

Ved regranskning av MR-bildene ble primærbeskrivelsen opprettholdt. Det var ikke primært mistanke om multippel sklerose og det var ikke påfallende markerte kartegninger. Intramedullær kontrastladning i nedre del av medulla til konus, spesielt anteriort, var diffus og med utseende som myelitt.

Utredning med somatosensorisk fremkalt respons (SEP) viste at respons manglet bilateralt i tibialis, men var normal i medianus. Visuelt fremkalt respons (VEP) og auditivt fremkalt respons (AER) var normale. Emisjonscomputertomografi (PET-CT) viste normalt opptak i medulla. Spinalvæsken var negativ for nevrotrope virus. Proteinnivået var o,59 g/l $(0,15-0,55)$, det var $1 \cdot 10^{6} / 1$ celler $(<5)$ og ingen oligoklonale bånd. Akvaporin 4-IgG-antistoff i 
serum var negativ, og det var ikke kliniske tegn til synsnervebetennelse.

Fremkalt respons-undersøkelser gir informasjon om ledningsevnen i sentralnervesystemet (4). Somatosensorisk fremkalt respons benyttes til å bedømme ledningshastighet og demyelinisering i bakstrengsystemet og til prognosevurdering ved anoksisk hjerneskade. Auditivt fremkalt respons brukes til å lokalisere sykdom i pontine hørselsbaner, mens visuelt fremkalt respons brukes oftest til å dokumentere gjennomgått synsnervebetennelse.

Pasienten hadde gangvansker, og MR viste kraftig ødem og kontrastladning som ved myelitt, med en langstrakt lesjon over 6-8 vertebrale segmenter. Myelitt karakteriseres av akutt eller subakutt innsettende pareser og ofte påvirkning av andre ryggmargsfunksjoner, med inflammatoriske forandringer i medulla. Tilstanden kan forårsakes av demyeliniserende sykdommer, infeksjoner (for eksempel borrelia og nevrotrope virus som herpes eller varicella), systemisk autoimmun sykdom som sarkoidose, systemisk lupus erythematosus, Behçets sykdom og paraneoplasi.

Neuromyelitis optica eller nevromyelittspektersykdom (NMOSD) var aktuelle differensialdiagnoser på grunn av lesjonens utbredelse. Disse tilstandene rammer primært synsnerver og ryggmarg med inflammatorisk demyelinisering, men også cerebrale strukturer. Tilstanden skilles fra multippel sklerose ved typisk langstrakte medullære lesjoner over tre vertebrae og ofte normale funn ved MR av hjernen. Patofysiologisk mekanisme er astrocyttskade, og ikke oligodendrocyttap som ved multippel sklerose. Sykdommen klassifiseres etter tilstedeværelse av akvaporin-4-antistoff, som finnes hos 40-70\% av pasienter med neuromyelitis optica og enkelte med nevromyelittspektersykdom (5). Tilstanden kan være paramalign (6).

Ny intravenøs behandling med metylprednisolon ble startet, med tillegg av $60 \mathrm{mg}$ prednisolon daglig gitt peroralt. Ved kontroll etter seks uker rapporterte pasienten noe bedring, men fortsatt varierende symptomer. Pasienten hadde tidvis behov for rullestol og ellers rullator. Grunnet urinretensjon måtte han urinkateteriseres. MR viste relativt uendret diffust ødematøs oppdriving av nedre medulla, med noe mindre utbredelse. Etter seks uker med prednisolonbehandling var det altså kun en marginal bedring klinisk og radiologisk. Pasienten hadde fortsatt betydelige gangvansker og behovet for urinkateterisering hadde økt. Han opplevde bivirkninger etter langvarig steroidbehandling. På grunn av alvorlige symptomer med tentativ diagnose myelitt av ukjent, antatt autoimmun årsak, ble det igangsatt behandling med 1 ooo mg intravenøst administrert rituksimab med to ukers mellomrom.

Ved myelitt kan intravenøs metylprednisolon forkorte forløpet, men har ikke sikker betydning for langtidsprognosen (7). Rituksimab er et monoklonalt antistoff mot CD 20 på B-lymfocytter. Det ødelegger normale og maligne B-lymfocytter, men ikke plasmaceller, og brukes i behandling av lymfom og leukemi samt en rekke autoimmune sykdommer. Studier har vist effekt av rituksimab ved demyeliniserende tilstander $(8,9)$.

Pasienten ble innlagt til planlagt kontroll fire måneder etter rituksimabbehandlingen. I mellomtiden hadde han vært på rehabiliteringsopphold og trent godt. Han opplevde likevel ingen sikker bedring. Anamnesen ble gjennomgått på nytt og han ble igjen nøye undersøkt klinisk. Sykehistorien var påfallende ved at graden av symptomer kunne forandre seg dag for dag. Innleggelsesdagen kunne han gå uten støtte 20-30 meter, hvilket ville vært umulig dagen før. Funn ved nevrologisk undersøkelse varierte avhengig av om han ble undersøkt liggende eller sittende, hvilket ikke hadde blitt bemerket tidligere. Anamnese og kliniske funn ble formidlet til radiolog. Ny MR av ryggen viste uendret intramedullært ødem fra midtre torakalmedulla til konus med vedvarende patologisk kontrastopplading. Det var prominerende karstrukturer omkring medulla (figur 1), og dermed mistanke om arteriovenøs fistel. MR angiografi og spinal digital subtraksjonsangiografi (DSA) viste fistel i nivå L3, forsynt fra venstre L3lumbalarterie og intradural refluks til perimedullære vener (figur 2). Nevrokirurg utførte stenging av dural arteriovenøs fistel ved hjelp av hemoklips (figur za og b). 


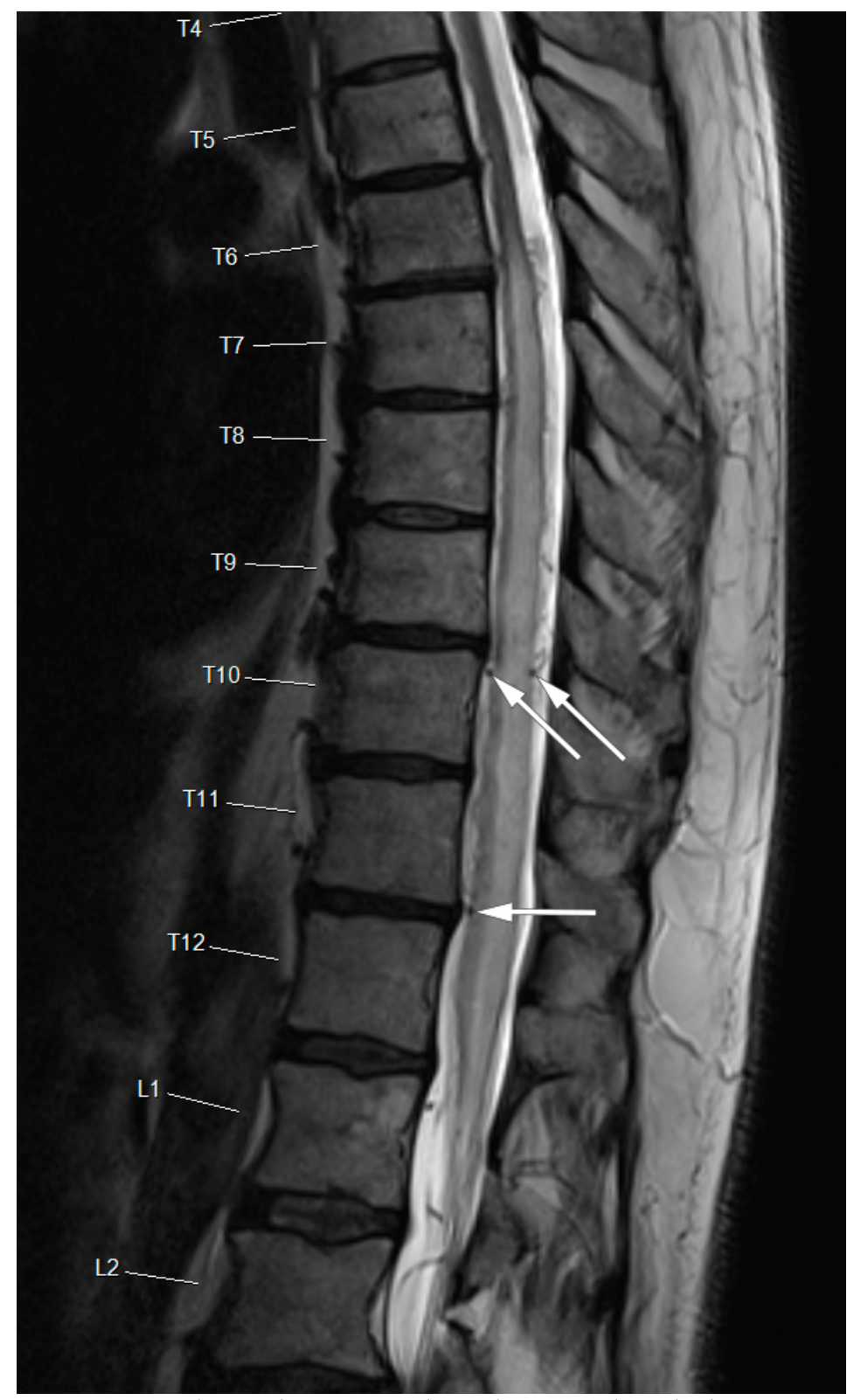

Figur 1 Sagittalt T2-vektet MR av Th-L-columna. Volumøkt, hyperintens medulla med sentralt ødem (Th6-L1). Signaltap (flow void) i dilaterte vener på medullas overflate (piler). 


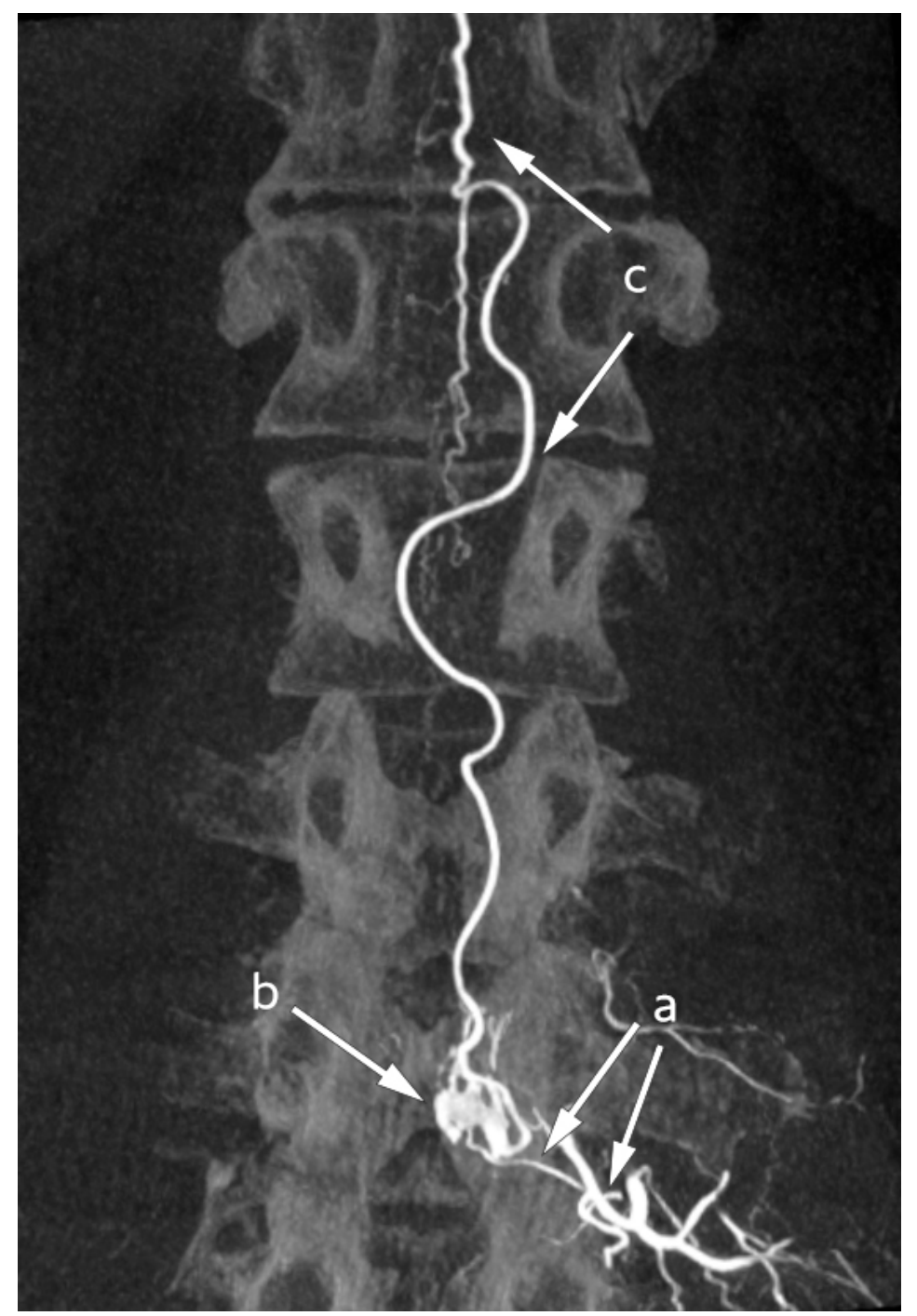

Figur 2 Koronal maksimal intensitetsprojeksjon (MIP)-reformatering av spinal $3 D$ rotasjonsangiografi. Selektiv injeksjon av kontrastmiddel $i$ venstre L3-lumbalarterie viser tilførende arterie (a), fistelsted og venøs ektasi (b) og dilaterte drenerende vener intraduralt (c).

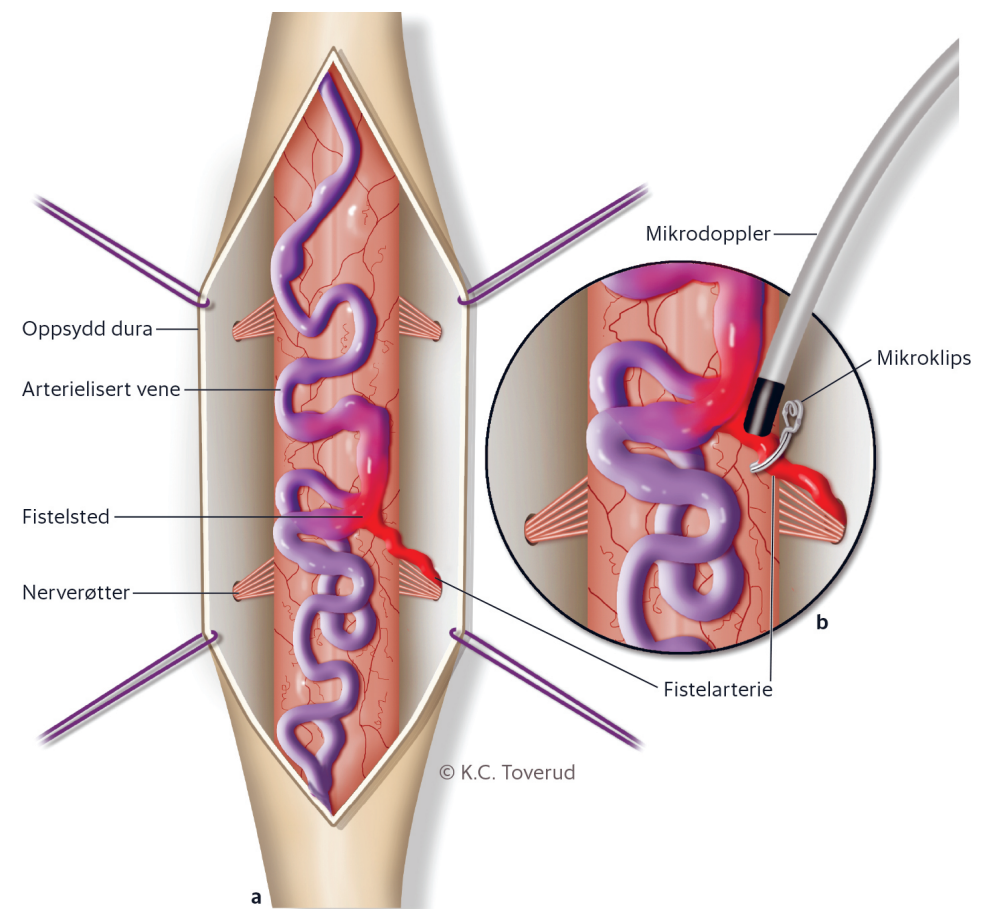

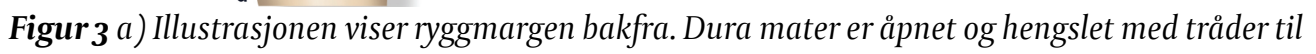
sidene. På ryggmargen sees dilaterte slyngede arterialiserte vener med forhøyet trykk. Fistelarterien entrer typisk gjennom dura mater der nerven kommer inn. Den går videre intraduralt langs med nerveroten, vanligvis som en enkel patologisk arterie. På ryggmargens overflate tømmer arterien seg 
så direkte i venesystemet uten mellomliggende kapillcrer. b) En mikrodopplerprobe brukes til å verifisere den patologiske arterien og blodstrømmens retning. Fistelarterien er stengt med et klips $i$ god avstand til selve fistelstedet.

Ved kontroll tre måneder etter operasjonen opplevde pasienten en klar bedring og ikke lenger svingende dagsform. Han hadde ikke behov for rullestol. Gangdistanse uten støtte var 200-300 m. Blærefunksjonen var bedre og behovet for fast kateterisering var borte. Pasienten kjente fortsatt antydning til stivhet og smerter, spesielt i hamstrings, og måtte ta hyppige pauser. Ved nevrologisk undersøkelse ble det funnet uendret sensibilitetsnedsettelse distalt i bena, med gradvis normalisering ved Th1o. Ved testing på benk var det kraftgrad 4 i bena. Det var ikke lenger sikker forskjell mellom kraftprestasjon $\mathrm{i}$ liggende og sittende stilling. MR medulla viste tilnærmet normalisering.

\section{Diskusjon}

Spinale durale arteriovenøse fistler utgjør om lag $70 \%$ av alle spinale arteriovenøse malformasjoner og har en insidens på 5-10/1 ooo ooo per år (10, 11). Forandringene sitter ofte torakolumbalt. Patofysiologisk mekanisme er antatt å bestå av venøs hypertensjon, som gir sekundært ødem og som kan føre til medullær venøs iskemi. Det kan også tilkomme mindre hematomer. Diagnose stilles gjennomsnittlig 11-18 måneder etter symptomstart, og tilstanden er ofte feildiagnostisert som spinalstenose, demyeliniserende sykdom, transvers myelitt eller spinal tumor (11).

Peri- og intramedullære arteriovenøse malformasjoner gir vanligvis symptomer i 20-30 års alder, mens durale fistler oftest blir symptomatiske i 40-50 års alder. Tilstanden diagnostiseres hos dobbelt så mange menn som kvinner. Årsaken til kjønnsforskjellen er ukjent $(10,11)$.

MR kan vise fortykket medulla med sentralt $ø$ dem og eventuelt dilaterte intradurale vener med tydelig signaltap (flow void). Ved MR angio kan man få fremstilt de patologiske venene og eventuelt dural fistel. Digital subtraksjonsangiografi brukes for å påvise og lokalisere den arterielle forsyningen til den durale fistelen. I to nylige studier fant man at ødemutbredelse på MR korrelerte med postoperativt funksjonsnivå $(12,13)$ på Aminoff-Logue disability (ALD)-skalaen, der funksjon graderes ut ifra gangfunksjon og vannlatingsforstyrrelser (14).

Behandlingen er enten nevrokirurgisk med åpen kirurgi eller nevroradiologisk med endovaskulær lukking ved hjelp av flytende emboliserende materiale. Behandlingsmåten avgjøres av fistelens tilgjengelighet, pasientens alder og komorbiditet. Åpen kirurgi velges såfremt det ikke er kontraindikasjoner og gir 94-100 \% obliterasjonsrate (15). Radiologisk, endovaskulær intervensjon har lavere lukningsgrad $(15,16)$. Målet med stenging av fistelsted er å eliminere blodstrømningen gjennom fistelovergangen og dermed gjenopprette normal medullær perfusjon og intravaskulære trykkforhold.

Den kirurgiske prosedyren gjøres som oftest under kontinuerlig nevrofysiologisk monitorering med somatosensorisk fremkalt respons og motorisk fremkalt respons for optimal informasjon om ryggmargsfunksjonen under inngrepet. Operasjonen utføres under generell intubasjonsnarkose med pasienten i mageleie. For tilgang til spinalkanalen fjernes lamina med den skråstilte ryggtaggen (prosessus spinosus) ved hjelp av ultralydkniv. Deretter gjøres mikrokirurgi der først dura mater, og så arachnoidea, åpnes langsgående i fistelnivå slik at karstrukturene på ryggmargens overflate visualiseres (figur 3a).Varsom disseksjon for lokalisering av den aktuelle dorsale nerveroten leder så til fistelstedet. Mikrodoppler registrerer blodstrømmens retning og hastighet slik at den patologiske arterien og fistelstedet kan verifiseres. Selve fistelen stenges med mikroklips, og fistelen klippes mellom disse (figur 3 b).

Langtidsprognosen avhenger av preoperative symptomer. Bedring av motoriske utfall kan finnes hos $80 \%$, mens sensoriske utfall bedres hos under $50 \%(16,17)$. Jo mer symptomer før kirurgi, jo dårligere er prognosen. Høyt symptomtrykk bør heller fremskynde enn forhindre behandling (11). 
Vår pasient fikk diagnosen i underkant av ett år etter symptomdebut. Dette er i samsvar med gjennomsnittlig diagnosetidspunkt for spinale durale arteriovenøse fistler $(11,12)$. Retrospektivt kunne diagnosen ha blitt stilt tidligere dersom vi hadde lagt sterkere vekt på anamnesen (posisjonsavhengige utfall og betydelig symptomfluktuasjon) og mindre vekt på de første MR-funnene. Den opplevde forverringen under steroidbehandling er rapportert tidligere og kan skyldes forbigående lokal steroidindusert væskeretensjon med $\emptyset \mathrm{kt}$ medullært ødem via økt venøst trykk (18).

Spinal dural AV-fistel er en underdiagnostisert tilstand (19) og bør særlig mistenkes hos middelaldrende personer med nyoppstått myelopati som ikke responderer på vanlig steroidbehandling. Hvis symptomene øker ved Valsalva-manøver, stillingsendring eller varierer over kort tid, er det enda større grunn til mistanke (10, 11).

Over de neste 18 månedene fant vi fire lignende tilfeller, hvilket viser at man gjerne finner det man er oppmerksom på. Lang symptomvarighet før diagnostisering indikerer også at diagnosen ofte blir oversett i begynnelsen.

Ny gjennomgang av anamnese, gjentatt klinisk undersøkelse med påvist diskrepans i kraftprestasjoner i liggende og stående posisjon, kombinert med gjentatt MR/MRangiografi av ryggen ga diagnosen i dette tilfellet. I en klinisk hverdag der avanserte supplerende undersøkelser ofte er lett tilgjengelige, minner denne kasuistikken oss om at refleksjoner rundt anamnese og kliniske funn er avgjørende for å kunne stille riktige spørsmål til undersøkelsene vi bestiller.

\section{LITTERATUR:}

1. Seehusen DA, Reeves MM, Fomin DA. Cerebrospinal fluid analysis. Am Fam Physician 2003; 68: 1103-8. [PubMed]

2. Gjerstad L, Skjeldal OH, Helseth E. Nevrologi og nevrokirurgi. Fra barn til voksen. 3. utg. Nesbru: Forlaget Vett \& Viten, 2003 .

3. Håndbok for nevrologi. Cerebral småkarsykdom.

https://nevrologi.legehandboka.no/handboken/sykdommer/cerebrovaskulare-sykdommer/sykdomm er-og-symptomer/cerebral-smakarsykdom/ Lest 12.8.2019.

4. Sand T, Kvaløy MB, Wader T et al. Fremkalt-respons undersøkelser i klinisk diagnostikk. Tidsskr Nor Legeforen 2013; 133: 960-5. [PubMed][CrossRef]

5. Wingerchuk DM, Banwell B, Bennett JL et al. International consensus diagnostic criteria for neuromyelitis optica spectrum disorders. Neurology 2015; 85: 177-89. [PubMed][CrossRef]

6. Cai G, He D, Chu L et al. Paraneoplastic neuromyelitis optica spectrum disorders: three new cases and a review of the literature. Int J Neurosci 2015; 126: 66o-8. [PubMed][CrossRef]

7. West TW. Transverse myelitis-a review of the presentation, diagnosis, and initial management. Discov Med 2013; 16:167-77. [PubMed]

8. Pellkofer HL, Krumbholz M, Berthele A et al. Long-term follow-up of patients with neuromyelitis optica after repeated therapy with rituximab. Neurology 2011; 76: 1310-5. [PubMed][CrossRef]

9. Spelman T, Frisell T, Piehl F et al. Comparative effectiveness of rituximab relative to IFN- $\beta$ or glatiramer acetate in relapsing-remitting MS from the Swedish MS registry. Mult Scler 2018; 24: 1087-95. [PubMed][CrossRef]

10. Koch C. Spinal dural arteriovenous fistula. Curr Opin Neurol 2006; 19: 69-75. [PubMed][CrossRef]

11. Lee J, Lim YM, Suh DC et al. Clinical presentation, imaging findings, and prognosis of spinal dural arteriovenous fistula. J Clin Neurosci 2016; 26:105-9. [PubMed][CrossRef]

12. Ofran Y, Yovchev I, Hiller N et al. Correlation between time to diagnosis and rehabilitation outcomes in patients with spinal dural arteriovenous fistula. J Spinal Cord Med 2013;36: 200-6. [PubMed][CrossRef]

13. Yen PP, Ritchie KC, Shankar JJ. Spinal dural arteriovenous fistula: correlation between radiological 
and clinical findings. J Neurosurg Spine 2014; 21: 837-42. [PubMed][CrossRef]

14. Aminoff MJ, Logue V. The prognosis of patients with spinal vascular malformations. Brain 1974; 97: 211-8. [PubMed][CrossRef]

15. Steinmetz MP, Chow MM, Krishnaney AA et al. Outcome after the treatment of spinal dural arteriovenous fistulae: a contemporary single-institution series and meta-analysis. Neurosurgery 2004; 55: 77-87. [PubMed][CrossRef]

16. Narvid J, Hetts SW, Larsen D et al. Spinal dural arteriovenous fistulae: clinical features and longterm results. Neurosurgery 2008; 62: 159-66. [PubMed][CrossRef]

17. Ma Y, Chen S, Peng C et al. Clinical outcomes and prognostic factors in patients with spinal dural arteriovenous fistulas : a prospective cohort study in two Chinese centres. BMJ Open 2018; 8. doi: 10.1136/bmjopen-2017-01980o. [PubMed][CrossRef]

18. Rain S, Udding J, Broere D. Acute clinical worsening after steroid administration in cervical myelitis may reveal a subdural arteriovenous fistula. Case Rep Neurol 2016; 8: 234-42. [PubMed][CrossRef]

19. Gade Sundbye FB, Karabegovic S, Birkeland P. The spinal dural arteriovenous fistula is an underdiagnosed vascular malformation. Ugeskr Laeger 2018;180: V10170723. [PubMed]

Publisert: 9. desember 2019. Tidsskr Nor Legeforen. DOI: 10.4045/tidsskr.18.0841

Mottatt 26.10.2018, første revisjon innsendt 8.4.2019, godkjent 7.10.2019.

(C) Tidsskrift for Den norske legeforening 2020. Lastet ned fra tidsskriftet.no 